\title{
Urban- Rural Marketing Linkage Practices and Challenges Evidences from Ambo Town West Shoa Zone, Orimia Regional State, Ethiopia
}

\author{
Negash Geleta \\ Lecturer of Ambo University, College of Business and Economics, \\ Department of Management, P.O. Box: 19, Ambo University, Ethiopia
}

\begin{abstract}
The objective of study was to assess the practices and challenges of rural-urban marketing linkages in Ambo Town. The study may be used to show the gaps between urban and rural on the marketing of agricultural products. The study was used descriptive research design. The populations of the study were some selected retailers and farmers those participate on the marketing of agricultural products. For sample size determination Yemane Taro formula was used and accordingly 187 sample size was employed. To identify this sample random sampling was used to select the research subjects from the population. As the source of information primary data was employed using structured questionnaire. For data analysis descriptive statistics was employed. Based on the data collected the findings of the study show that the production linkages were very weak which was reflected mainly in case of poor connection in the between urban and rural. However, a strong consumption linkage was observed as farmers tend to purchase goods and services from the Town. The insufficient crop production had made the existing marketing linkage to be expressed only in the form of exchange of products. Financial linkage was further strengthened even through all are not connected with rural farmers. Finally, the research recommended that urban and rural oriented linkage must be practiced which need further strengthen for the existing financial linkages and production linkage as it provides opportunity for existing traders in the Town.
\end{abstract}

Key terms: Urban- Rural Linkage, Marketing, opportunities, challenges

DOI: $10.7176 / \mathrm{CER} / 12-8-02$

Publication date:August $31^{\text {st }} 2020$

\subsection{Background of the study}

The relative emphasis placed on rural-urban area in the development policies of developing countries has shown considerable variation over time from industrial development in urban area to integrated rural development. (Chowdhury et.al., 2005). Until 1970's, literature on development planning in third world countries considered agriculture \& industrial sectors as somewhat separate \& sometimes conflicting aspects (Mesfin, 1995). Development planners had focused on allocating resources on the basis of either sectoral (agriculture or manufacturing) or spatial (rural or urban area) approach (Mohammed, 2007). According to Tegegne (2001) most pro-poor \& anti poverty initiatives remain steadfast to discrete urban or rural domains. But later this view was changed more attention paid to the role of urban centers in the rural economy (Mesfin, 1995; Tacoli, 2008). As a concurrent trend, development researchers advocated for the role of the agriculture sector as the engine of growth in developing countries. For that matter, increased agriculture output is considered as the only hope for better standard of living for many third world countries (Tegegne, 2001). Though IRD helped to promote some non-agriculture activities in rural area, their focus was primarily on planning in the rural agriculture sector \& projects usually did not consider potential linkages with urban policy (Douglass, 1998). Integrated Rural Development Programs (IRDPs) over emphasized the farmer \& rural agriculture, with little if any attention to the role of urban centers in the rural economy (Tacoli 1998). As a result, the expected economic development did not materialize because the rural poor had limited access to inputs $\&$ credits. In addition, it was also mentioned that the neglect of the urban aspects of rural economy had undermined the development of potential rural area (Mohammed, 2007). IRDP has also failed simply because there was a neglect of the urban dimension in the development process (Tegegne, 2001). In line with this, recently, there is a growing recognition of the importance of focusing on the mutual interdependencies, rather than the "separateness" of rural \& urban area because the livelihoods of rural \& urban households rely both on "rural-based" \& "urban-based" resources as well as the exchanges between the two area (Chowdhury et al., 2005). This mutual development is manifested through URLs (IFS, 2005; Mohammed, 2007; Munankami, 2005; Okpala, 2003; Tegegne, 2001). The positive impact of URLs on rural \& urban livelihoods is summarized in the 'virtuous circle', where rural \& urban development is mutually dependent \& integrated (Tacoli, 1998). These activities would in turn have a capability to attract surplus labor \& increase demand for rural \& agriculture produces (Tegegne, 2005). The URLs are crucial elements for economic growth \& contribute to poverty reduction by enabling households \& individuals to expand their options for income generating activities (Adebayo, 2005). In other words, there is a need to gain better understanding of the relationships between urban $\&$ rural area $\&$ the variety in the nature of these linkages 
(Okpala, 2003). This study aims to look at practices and challenges of rural-urban linkage on agricultural marketing of Ambo Town West Shoa Zone Ethiopia.

\subsection{Problem Statement}

The development strategies of Ethiopia have been formulated with either urban or rural focus (Tegegne, 2005). Such kind of development strategy with unbalanced focus on either rural or urban centers as poles of economic growth \& development undermines the fertile opportunities for sustainable economic development that could be tapped from coordinated URLs (Gete, 2007). To realize the positive role of towns \& rural linkage, policies should be matched by specific measures \& programs should aim at rural-urban linkages. Thus, investigation of the rural-urban linkage is an important issue in order to address the rural \& urban socio-economic development. Livelihood is a multifaceted concept, being what people do; what they accomplish by doing it, referring to outcomes as well as to activities. "Ways can be sought to multiply livelihoods by increasing resource-base intensity \& the diversity \& the complexity of small-farming livelihood systems \& by small-scale economic synergy (Chambers \& Conway, 1991:1). In order to understand livelihood, understanding migration, right \& access to natural resources, local non-farm income \& formal employment are important. This implies that there is a demand for rural-urban linkage. Haidar (2009) stated that, the positive livelihood outcomes are influenced by the people's access to assets \& the policies, institutions \& the processes that affect their ability to use the asset. Sustainable livelihoods can serve as a useful approach to investigate the interactions among different factors that bear influence on livelihoods (Soussan et al., 2003). Though there is a vast volume of literature on the subject of rural-urban linkages, there are gaps in knowledge about the effects that URLs have on socioeconomic development $\&$ the factors that determine such linkages in case of marketing. In particular, the nature of ruralurban linkage \& its role in the rural livelihoods using the sustainable livelihood framework has not been well studied in Ethiopia. Those who have made studies in URLs have tried to treat issues like farm \& non-farm linkages (Tassew 2002), linkages under different farming systems in Robe \& Limu (Tegegne, 2001), livelihood strategies \& their implications for URLs in Wolenkomi (Mohamed, 2007), natural resource management \& URLs in Ethiopian highland (Carucci \& Yihenew, 2007) \& market linkages in Western Shoa Zone (Mesfin, 1995 ) but all these were not focused in case of marketing linkage. Then this study planned to examine the urbanrural marketing linkage practices and challenges evidence from Ambo Town West Shoa Zone Ethiopia.

\subsection{Study Objectives}

1. To reveal the existing practices of rural-urban marketing linkages of Ambo Town.

2. To explore the challenges of rural-urban linkage marketing in the study area.

\subsection{Significance of the Study}

The mutual development of rural and urban area is the preferred as development strategy in any country. The balanced development between rural and urban area can be achieved if the two spatial settings interact. The linkage may be helpful in promoting equitable development of the two spatial units and also planners and policy makers. It also helpful for local government bodies in particular for practitioners and policy makers in general, by providing evidence regarding the contribution of rural-urban linkage, in improving economic development and poverty alleviation. It shows the entry points of strategies that are vital in alleviating poverty and improving livelihoods. Assessing the role of the existing RUL on the rural livelihoods would have its contribution in filling the gap in the literature. The outcome of this study makes a modest contribution to research methodologies. On top of this, finding of the research work could also give an insight for researchers and students interested in similar theme for further investigation in other area or to conduct an in-depth study on RULs or other related issues.

\subsection{Scope of the Study}

The delimitation sections of study clarify the criteria of participants to enroll in the study, the geographic region covered in study, and the profession or organizations involved and theoretical study. First, this study was delimited to urban-rural marketing linkages of Ambo Town. Second this study was delimited to practices and challenges of Rural-Urban marketing Linkage.

\section{Literature Review}

The term rural-urban linkage generally refers to the growing flow of capital (private \& public), people, goods (trade), ideas, information \& diffusion of innovation between urban \& rural area. In this rural-urban linkage, accessibility of adequate infrastructure like transportation, communication, energy \& basic services is a pillar for successful linkage. Adequate investments in infrastructure improve the rural productivity \& allow access to market, jobs \& public service. Efficiency \& effectiveness of infrastructure \& other institutions are important in facilitating the linkages (Braun, 2007; Okpola, 2003). Urban \& rural area is tightly connecting with each other. 
These connections display as resource flows of people, capital, information, goods \& technology between them. There is an existence of social, economic \& environmental interdependence between urban \& rural area. According to Tesfaye (1993: 59) "Urban \& rural area are interdependent \& linked in almost all spheres of economic, social, political \& cultural life". The encouragement of these URLs is critical for improving the economic capacity \& quality life of the majority of people in Africa. Promoting rural urban linkages offer considerable potential for developing the entire rural-urban continuum (Demeke, 1998; Lynch, 2005). URLs include flows of agriculture \& other commodities from rural based producers to urban markets, both for local consumers \& for forwarding to regional, national \& international markets; \&, in the opposite direction, flows of manufactured \& imported goods from urban centers to rural settlements.

\subsection{Urban-Rural Marketing Linkages}

The rural service center strategy on the other hand focused on small centers for their own development \& that of the rural. These rural service centers provide markets for agriculture produce $\&$ increase productivity, extension, administrative services, education \& health services. These centers are considered as engines of growth. They have a contribution for the productive capability of the rural producers $\&$ they promote the commercialization $\&$ specialization of agriculture in framework of national economic growth (Demeke, 1998; Tegegne, 2001). The most common types of linkages that are produced from the connection of both rural area $\&$ urban centers are:

Production linkage: This is created when the farm households use agriculture inputs available in the Town \& the Town's enterprise use agriculture products as raw material for their activities (Tassew, 2002; Tegegne, 2001). Consumption linkage: It is produced when the rural households' income obtained from the sale of agriculture produce is spent to purchase consumer goods \& services available in the nearby Town. It represents the flow of consumption goods \& services across the rural-urban continuum (Tassaw, 2002; Tegegne, 2001).

Marketing linkage: It refers to the selling \& buying of goods. In other words rural households sell their agriculture produce to urban households \& trades in the market of small Towns (White, 2005).

Public service linkage: This emanates when the rural households use the public services available in the small Towns (Tegegne, 2001).

Environmental linkage: This is manifested when there is flow of natural resources between the two spatial units. Natural resource such as water, fire wood, construction materials etc flow from the surrounding rural area to the nearby urban center. \& wastes are deposited in rural area from the urban.

Tourism linkage: This involves a situation when people move away from their permanent residence for recreation, holiday, visiting relatives \& the like for short period of time (MoWUD, 2009).

Infrastructural linkage: This could be physical (such as road \& telecommunication) or social infrastructure (like schools, health centers). These infrastructures are expected to provide adequate service to the rural people (MoWUD, 2009).

Demographic linkage: the two spatial units are linked by rural to urban \& urban to rural migration in which labor is the major flow of resource. Migration is one of the few avenues open to poor households to increase income \& combat increasing impoverishment (MoWUD, 2009).

Financial Linkage: The movement of capital between rural \& urban area is effected through financial intermediaries. This is the flow of capital through formal (banks \& microfinance) \& informal (money lender, relatives \& friends) institutions between rural \& urban area. It includes remittances from migrants to relatives \& communities in sending area $\&$ investments \& credit from urban-based institutions (NUPI \& MFA, 2003; Tacoli, 2004).

Economic Linkages: Hence, selling of goods \& services produced in one settlement to another marks the trading \& commercial relationships between Towns \& the surrounding rural area as Towns provide access to markets \& serve as means of livelihood for the rural communities (Tostensen, 2004). Moreover, rural-urban linkage enhances diversification of means of livelihood both in rural \& urban settings. In the rural area, rising agriculture wage was raising the opportunity costs of labor in the nonfarm activities. This induces a shift in the means of livelihood composition in terms of labor intensity, returns to investment, \& skill requirements.

\subsection{Challenges of Rural Urban Marketing Linkages}

As the existing rural-urban linkage is limited, the challenges are numerous. These Challenges range from some policies to the functioning of the socio-economic environment. Elements of the rural land tenure policy pose a great threat to enhancing rural urban linkage in Ethiopia. Rural land is publicly owned. Individuals have a usufruct rights. In order for this right to be exercised physical presence is considered as essential criteria. This has twofold: impacts on rural urban linkage. In the first instance, it discourages farmers' mobility to urban area thereby limiting the flows of people (Tegegne, 2005). Secondly, the requirement was not give a chance for urban small entrepreneurs to engage in rural farming activities. Hence, the flows of resources \& people from urban to rural in a temporary or permanent way was highly limited. Marketing has a very significant role in rural-urban linkages. Markets are provided by small, medium \& large Towns. The limited flow of finance to rural area from 
commercial \& development banks was reduce the development of rural area \& hence limit the linkages urban area was have with the rural area. In addition, the limited capacity of the existing MFIs to adequately cover \& meet the demands of rural finance is a strict limitation for increased flow of finance from urban to rural area (Fasika \& Daniel, 1997). Agro processing industries in Ethiopia are few. Those, which have high potential, have a higher import content signifying the limited linkages. The fact that industries import most of their raw material is a threat for backward linkages expected from these industries. $\mathrm{S}$

\section{Methodology}

3.1. Study Area: The study was conducted in the Oromia regional state West Shoa Zone at Ambo Town. As the part of West Shoa Zone, Ambo is located $112 \mathrm{Kms}$ West of the capital Addis Ababa.

3.2. Research Design: The research used quantitative methods. Then the data were collected using quantitative research approaches by employing descriptive research design. This design was used to describe factors that influencing the practice and challenges of Rural-Urban Linkage on marketing at Ambo Town. This research design helps to gather data from a relatively large number of cases at a particular point in time.

3.3. Data Types \& Sources: For data collection primary data was used from retailers \& sellers of primary products. Information related to marketing linkage, consumption \& expenditure was gathered from urban dweller. This data was collected in June, 2020.

3.4. Population, Sample size and Sampling Methods: The target populations of the study were retailers and primary product sellers found in Ambo Town which account about 2264 and about 50 urban traders/retailers respondents from different categories of traders in the Town. From the total population of 2264 farmers those sell their products in the town about 187 samples of household was calculated by using (Yamane, 1967) formula. Accordingly, the required sample size at $7 \%$ level of precision to obtain a sample size required which represent a true population.

$$
\mathbf{n}=\frac{\mathbf{N}}{1+\mathrm{N}(e) 2} \quad \mathbf{n}=\frac{2264}{1+2264(0.07) 2}=\underline{\underline{187}}
$$

Where, $n=$ sample size, $N=$ population $s$ (sampling frame) \& $e=$ level of precision $7 \%$.

As its name implies, convenience sampling refers to the collection of information from members of the population who are conveniently available to provide it. Then as it is difficult to get all the farmers in one place and give chance at the same time the researcher used convenience sampling to reach the sample size at the convenience place.

3.5. Data Collection Instrument: Structured questionnaire was designed separately to collect data from rural households selling their products at the Ambo Town \& traders.

3.6. Methods of Data Analysis: The quantitative data was analyzed using SPSS v. 23 using descriptive statistics frequency (percentages). This more important to show the present conditions of the rural-urban marketing linkages in the ambo town.

4. Result \& Discussion: Descriptive statistics were employed to describe the characteristics of sample farmers $\&$ traders. From the sample of 187 households 172 were available for data analysis. The left 15 is not suitable for analysis in case of some errors \& was not returned on time. The data collected \& used for analysis was about $91.98 \%(172 / 187)$. Then, this is sufficient \& enough to continue data analysis. 


\subsection{Profiles of Respondents}

Table 4.1a. Profiles of Rural Households

\begin{tabular}{|l|c|c|c|}
\hline Characteristics & Category & Frequency & Percentage \\
\hline \multirow{4}{*}{ Sex } & Male & 133 & $77 \%$ \\
\cline { 2 - 4 } & Female & 39 & $23 \%$ \\
\cline { 2 - 4 } & Total & $\mathbf{1 7 2}$ & $\mathbf{1 0 0 \%}$ \\
\hline \multirow{3}{*}{ Age } & $20-30$ & 79 & $46 \%$ \\
\cline { 2 - 4 } & $31-40$ & 61 & $35 \%$ \\
\cline { 2 - 4 } & $>41$ & 32 & $19 \%$ \\
\hline \multirow{4}{*}{3. Marital status } & Total & $\mathbf{1 7 2}$ & $\mathbf{1 0 0 \%}$ \\
\cline { 2 - 4 } & Single & 17 & $9.9 \%$ \\
\cline { 2 - 4 } & Married & 146 & $85 \%$ \\
\cline { 2 - 4 } & Divorced & 3 & $3.7 \%$ \\
\cline { 2 - 4 } & Widowed & 6 & $\mathbf{1 0 0 \%}$ \\
\hline \multirow{4}{*}{$4 . \quad$ Occupation } & Total & $\mathbf{1 7 2}$ & $89 \%$ \\
\cline { 2 - 4 } & Farmer & 153 & $11 \%$ \\
\cline { 2 - 4 } & Semi-trader & 19 & $\mathbf{1 0 0} \%$ \\
\hline
\end{tabular}

Sources: Survey Data 2020

Table 4.1 presents the basic demographic characteristic of rural households by constituting four characteristics. As it can be seen from the table the majority of the farmers were male which accounts about $77 \%$ $\&$ the left were females. The second characteristics were age. In this case the majority of the farmers' were range between 20-30 ages which accounts about $46 \%$ \&. Moreover, the majority of the respondents had married quite higher than others as presented in table 4.1 with $85 \%$. Finally in case of occupation only $11 \%$ of rural households were semi-trader while $89 \%$ were farmers.

Table 4.1b. Characteristics of Urban Traders

\begin{tabular}{|c|c|c|c|}
\hline variables & Category & Frequency & Percentage \\
\hline \multirow[t]{3}{*}{ 1. Sex } & Male & 157 & $91.28 \%$ \\
\hline & Female & 15 & $8.72 \%$ \\
\hline & Total & 172 & $100 \%$ \\
\hline \multirow[t]{4}{*}{ 2. Age } & $20-30$ & 57 & $33.14 \%$ \\
\hline & $31-40$ & 61 & $35.47 \%$ \\
\hline & $>41$ & 54 & $31.39 \%$ \\
\hline & Total & 172 & $100 \%$ \\
\hline \multirow[t]{5}{*}{ 3. Educational back ground } & Illiterate & 3 & $1.74 \%$ \\
\hline & Primary first cycle (1-4) & 5 & $2.91 \%$ \\
\hline & Primary second cycle (5-8) & 23 & $13.37 \%$ \\
\hline & Secondary $(>9)$ & 141 & $81.98 \%$ \\
\hline & Total & 172 & $100 \%$ \\
\hline
\end{tabular}

Source: Survey Data 2020

The basic demographic characteristic of the sample urban households is provided in table 4.2. About $91.28 \%$ of the sample households were male and the left about $8.72 \%$ were females. More of the age of the respondents ranges between $31-40$, which was account, about $35.47 \%$ of the sample of respondents. Education, which is a very important human capital component, is a potential indicator of a household's labor. The data on table 4.2 depicts $1.74 \%$ illiterate and the majority of the respondents were Secondary $(>9)$ which accounts about $81.98 \%$ of the samples.

\subsection{Existing Practices of URLs in the Study Area}

\subsubsection{URLs in Production}

Table 4.3 presents four items relating to Rural-Urban Production Linkages. The first one is land which is used as one of the production factor in the economic concept and used as the basic for the presence of URKs. Then land is an important natural capital for people residing in rural area. It is a critical production factor which determines the type of crops that are grown and the size of the crop harvests. Under the subsistence agriculture system, land holding plays a significant role in influencing crop production and households' food security. In this study only 0.6.4\% of respondents had no had their own land and the left about $93.6 \%$ households were had their own lands which enable them to produce production and supply to the markets. 
Table 4.2.Rural -Urban Production Linkages

\begin{tabular}{|c|c|c|c|}
\hline Items & Category & Frequency & Percentage \\
\hline \multirow[t]{3}{*}{ 1. Do have your own farm land? } & Yes & 161 & $93.6 \%$ \\
\hline & No & 11 & $0.6 .4 \%$ \\
\hline & Total & 172 & $100 \%$ \\
\hline \multirow{3}{*}{$\begin{array}{l}\text { 2. Did have you used fertilizer and improved seeds } \\
\text { last production year? }\end{array}$} & Yes & 133 & $77.33 \%$ \\
\hline & No & 39 & $22.67 \%$ \\
\hline & Total & 172 & $100 \%$ \\
\hline \multirow{4}{*}{$\begin{array}{l}\text { 3. Based on } \mathbf{Q}_{2} \text { if you have not used last production } \\
\text { year, what are the reasons for not using? }\end{array}$} & Lack of money & 27 & $69.23 \%$ \\
\hline & Lack of access & 2 & $5.13 \%$ \\
\hline & High cost & 10 & $25.64 \%$ \\
\hline & Total & 39 & $100 \%$ \\
\hline \multirow{3}{*}{$\begin{array}{l}\text { 4. Have you faced any problem on crop } \\
\text { production? }\end{array}$} & Yes & 153 & $88.95 \%$ \\
\hline & No & 19 & $11.05 \%$ \\
\hline & Total & 172 & $100 \%$ \\
\hline
\end{tabular}

Sources: Survey Data 2020

The second item discussed in table 4.3 is fertilizer and improved seeds as the farmer used in the last production year to see the connection was there between rural urban in selected area. As it is clear agricultural inputs help to increase agricultural productivity by healthful crops with minerals that are necessary for production and controlling pests and weeds. Therefore, Towns are expected to improve farmers' access to agricultural inputs. The extent to which farmers uses agricultural inputs and extension services, and the capacity Towns to provide these services to the farmers could reveal the impact or role of Towns on the farmers. Then regarding this concept the pattern of use of these inputs (fertilizer and improved seeds), commercial fertilizer (Urea and DAP) was the dominant in the study area. As table 4.3 shows, the greater part $(77.33 \%)$ of the sample rural households used fertilizers. The fertilizer was collected from the Town and distributed to the households in different Area by the cooperatives. Therefore, every household was not expected to visit the Town to collect the fertilizer. However, this does not mean that the households use sufficient amount of commercial fertilizer. Then still about $22.67 \%$ were not used these inputs because of high cost, lack of access and lack of money as presented in the above table. The last item in the table 4.3.is the problem of the farmers on crop production. However, households does not use sufficient amount of production inputs. The input providers from the twin were not well suited for crop production because of the agricultural products supplied to market from the suppliers were very small. A high share of farmers generated only small surpluses for market sales. As shown in table 4.3 the majority of the sample rural households (around $88.95 \%$ ) reported that they did not get all agricultural inputs from the Town. The main reason was the absence of surplus inputs in this area. Some farmers even bought seeds from the market. Most of the produces were produce "Teff", Wheat, Beans, and the like. Most of the persons who sold these produces in Ambo Town came from other nearby Woreda. Some of the 'Teff' that was available on the market came from nearby Area and some of it destined for markets in different market. Among the sample respondents, who sold their crop product last year, reported that they sold it directly to the consumers in the Town. This has its own implication on the income of the rural households as well as the customers. The existing marketing linkage via grain marketing was limited. This is in case of the farmers cannot combine a number of livelihood activities like agricultural crop production, livestock production, wage work, cottage industry etc. which are not provided from the Town. This information can support by since only $11.05 \%$ of households replied as there was no problem on production area in the selected Area.

\subsubsection{Agricultural Marketing}

Marketing linkage is manifested when the urban dwellers and traders purchase the agricultural produce from the rural households. Market is a place where products from both urban and rural area are exchanged between the suppliers and consumers. Market as a channel of exchange can either be formal, set by central or local government, or informal, where trade is spontaneously developed. 
Table 4.4.Rural -Urban Linkage Agricultural Marketing

\begin{tabular}{|c|c|c|c|}
\hline Items & Category & Frequency & Percentage \\
\hline \multirow{4}{*}{$\begin{array}{l}\text { 1. What type of agriculture you are } \\
\text { participating? }\end{array}$} & Crop production & 149 & $86.63 \%$ \\
\hline & Animal production & 13 & $7.56 \%$ \\
\hline & Both & 10 & $5.81 \%$. \\
\hline & Total & 172 & $100 \%$ \\
\hline \multirow[t]{3}{*}{ 2. Where did you sale? } & Ambo market & 109 & $63.37 \%$ \\
\hline & Any market & 63 & $36.63 \%$ \\
\hline & Total & 172 & $100 \%$ \\
\hline \multirow[t]{3}{*}{ 3. Why you prefer the market place? } & Proximity & 69 & $40.12 \%$ \\
\hline & Better price & 103 & $59.88 \%$ \\
\hline & Total & 172 & $100 \%$ \\
\hline \multirow{3}{*}{$\begin{array}{l}\text { 4. Is there any transportation problem that you } \\
\text { face to transport goods? }\end{array}$} & Yes & 167 & $97.09 \%$ \\
\hline & No & 5 & $2.91 \%$ \\
\hline & Total & 172 & $100 \%$ \\
\hline
\end{tabular}

Source: Survey Data 2020

Table 4.4 shows that small amount of producer participate in both (crop and animals,) which account about $5.81 \%$. About $86.63 \%$ of sample rural respondents confirmed that they participate on the crop production and the left one about $7.56 \%$ was participate on the animal production. The other item analyzed in the table was where did the farmers sale their production. In this case Towns are playing a worthwhile role of serving as a collecting and distributing center for the surrounding rural agricultural produce and thereby linking the rural with the wider regional and national economies. But some Towns could get agricultural produces from distant rural area or from another urban center due to unavailability or quality differences in agricultural produces. As depicted in table 4.4 , about $63.37 \%$ of the sample rural households' sale their production in the Ambo market and the left about $36.63 \%$ were sale to any market. As depicted in table 4.4 on the preference of the market place more the households prefer Better price which account about $59.88 \%$ and the left about $40.12 \%$ was prefer in case of proximity. Therefore, this shows that a considerable most of the household want to sell their products in good price in the market place. This also clearly showed how the rural farmers must be with urban markets. Finally in table 4.4 the transportation problem that face households' good transportation seen as one factor of URLs. In majority about $97.09 \%$ of the sample household uses their foot to come to the Town though they believed that there was transport problem in area. This was due to the there was no transportation facilities in the selected Area. It was only about $2.91 \%$ was travel by foot since they are neat to the Town. The average time to reach the Town was one hour and twenty minutes. Those who travelled on foot took them maximum of four hours. They used donkeys to transport items from home to the Town as well as from the Town to their home. Those with no donkey or other pack animal carried items on their back. Such long hours of travel may have its own impact on their production and contradicted with what the government sets to be the minimum distance farmers should to travel as some households replied during data collection.

\subsubsection{Consumption Linkage}

Town goods which are manufactured flow from urban to rural area. Activities that meet the consumer demand of rural households form the basic chain of consumption linkages. That is URLs occur when the rural households create demand for urban goods of small Towns. This becomes obvious when small Towns have the required goods and services in them for interactions to take place between rural area and urban centers. Towns are the major suppliers of consumer and manufactured goods to rural area.

Table 4.5. URLs ob the Purchases of consumer goods

\begin{tabular}{|ll|c|c|}
\hline \multirow{2}{*}{ Items } & \multicolumn{2}{|c|}{ Place Of Purchase } \\
\cline { 2 - 3 } & Ambo Town & Other place \\
\hline 1. & Clothing/ Shoe & 167 & $97.09 \%$ \\
\hline 2. & Building materials & 172 & $100 \%$ \\
\hline 3. Coffee/ Sugar/Tea/ Salt/ Spices/ Soap & 134 & $77.91 \%$ \\
\hline 4. Pepper/exercise book/pens & 155 & $90.12 \%$ \\
\hline 5. Oil/ Kerosene & $\mathbf{1 7 2}$ & $\mathbf{1 0 0 \%}$ \\
\hline
\end{tabular}

\section{Source: Survey Data 2020}

Table 4.5 revealed the households' consumption pattern relating to Ambo Town. With regard to goods, almost the entire sample farmers purchased consumables such as soap, kerosene, oil, sugar, and coffee from the Town market. This shows that Ambo was the major source for these goods. With regard to the place of purchase, a difference was observed among the sample of Area. Sample rural households who lived in the relatively far distant from the Ambo Town purchased their consumable items from kiosks (other place) found in the rural area. This was due the accessibility of the goods. But still for the most of the farmers purchase goods 
from the Town which was not found in the rural area for example such as oil and building materials which account about $100 \%$. Therefore, this result indicates that there was high connection but still it is some problems which still need more linkage between rural and urban.

\subsubsection{Existing Practices of Rural-Urban Services Linkage}

Table 4.6 discusses about Rural-Urban Services linkage since Service plays a great role in increasing agricultural productivity of the rural people. The whole sample respondents reported that they had got different services such as farm extension service, agricultural tools and veterinary services from the Town. Since this had a positive impact on strengthening rural-urban linkage in the study area. Households bought the modern technology from the Town. This shows that the production linkage between the Town and the rural must be strong. It is believed that the Farmers' Training Center would play a great role in improving the production capacity of the farmers and as a result improve their livelihood. The decisive goal of these FTCs is to improve the overall capacity of farmers to boost their production by equipping them with the necessary knowledge, skill and technology. According to the result from farmers some of farmers replied that in the first item about $81.98 \%$ as there is good agricultural service and the left $18.02 \%$ service reported as still there is some problem of URLs in the selected Area. This shows that though the government and the community spent large amount of money in constructing these FTCs, most of them were not functional. However, this does not mean they did not provide services at all. They were not changing the life of the farmers as expected. Such weak service of these FTCs had its own impact on weakening the rural-urban linkage through the low supply of agricultural productivity.

Table 4.6. Rural -Urban Services linkage

\begin{tabular}{|c|c|c|c|}
\hline Service Type & Category & Frequency & Percentage \\
\hline \multirow{3}{*}{$\begin{array}{l}\text { 1. Is there good agricultural service (tools purchase/ repair/ farm } \\
\text { extension service/ veterinary services) from Town? }\end{array}$} & Yes & 141 & $81.98 \%$ \\
\hline & No & 31 & $18.02 \%$ \\
\hline & Total & 172 & $100 \%$ \\
\hline \multirow[t]{3}{*}{ 2. Is there good schooling? } & Yes & 98 & $56.98 \%$ \\
\hline & No & 74 & $43.02 \%$ \\
\hline & Total & 172 & $100 \%$ \\
\hline \multirow[t]{3}{*}{ 3. Is there good health services and hotel services? } & Yes & 53 & $30.81 \%$ \\
\hline & No & 119 & $69.19 \%$ \\
\hline & Total & 172 & $100 \%$ \\
\hline \multirow[t]{3}{*}{ 4. Is there good telecommunication services? } & Yes & 117 & $68.02 \%$ \\
\hline & No & 55 & $31.98 \%$ \\
\hline & Total & 172 & $100 \%$ \\
\hline \multirow[t]{3}{*}{ 5. Is there good bank /loan service? } & Yes & 109 & $63.37 \%$ \\
\hline & No & 63 & $36.63 \%$ \\
\hline & Total & 172 & $100 \%$ \\
\hline
\end{tabular}

Source: Survey Data 2020

Education is without doubt very essential for development. Agricultural research that provide extension services and other inputs; and other technologies that increase production are gained through education. Moreover, the availability of schools and training centers is also essential for linking rural and urban area through the flows of human, cultural and financial elements. In this case about $56.98 \%$ of them reported the presence of good education service and the left $43.02 \%$ still need good services. Then as this result shows there is the lack of URLs in the selected area. In Ambo Town there are government hospital and health centers and as well as private health services. There were also livestock breeding and veterinary clinic that serve for both the rural farmers and urban dwellers. Hotels, bars, restaurants, bakery, barbershop and gas stations also found in the Town determined in providing services to both urban and rural people living in the study area. As presented in the table 4.6 majorities of the farmers replied as there is poor connection of URLs $69.19 \%$. Communication infrastructures like telephone are also important for social and economic activities of the communities. For example, telephone is one of the most important means of communication used by traders/farmers to obtain recent information needed for trade/sale the products. Hence, it has an impact on rural-urban linkages. In terms of telephone services, Ambo Town had digital telephone service, and the Area were beneficiary of the mobilephone service. There is high demand for the mobile phone, but the supply is very limited. Based on this facts table 4.6 shows that about $31.98 \%$ of the respondents reported that still there was problems of communication service in the selected area and the left about $68.02 \%$ respondents satisfied with the communication services in the area to support the URLs. Then this shows that still there is gap on the strengthening URLs which must be modified. Finally the financial linkage of Town to its rural discussed to see the availability of financial institutions in the Towns, which was stimulating the rural people to use these institutions for the loan and saving. As explained in above table about $36.63 \%$ of respondents still have problems to get access to financial institutions. In order to facilitate their service, the institutions made an arrangement by moving to the rural area 
even if they were based at Ambo Town. Then finally, the related institution must be focus on the improvement of URLs in case of financial issues.

\subsubsection{Rural-Urban Visiting pattern Linkage}

Social interactions between rural and urban area can be analyzed within the context of regular visits that occur mainly by the rural-based members. Nearby Towns are important to their rural people by providing several goods and services. Ambo Town was the most frequently visited center by all of the sample rural households. The frequency of sample rural households' visits to the urban area differs from household to household and from different Area and was likely to be influenced by factors such as the distance to the rural area, the purpose of the visit and the relationship of the household head to the urban-based household and family members. As shown in table 4.7 sample rural households visit Ambo Town based on the different issues. Almost 97.67\%of the respondents visited the Town frequently, while around $2.33 \%$ of the rural population was not visited the Town frequently.

Table 4.7.Rural -Urban Visiting pattern Linkage

\begin{tabular}{|c|c|c|c|}
\hline Items & Category & Frequency & Percentage \\
\hline \multirow[t]{3}{*}{ 1. Do you visit Town frequently? } & Yes & 168 & $97.67 \%$ \\
\hline & No & 4 & $2.33 \%$ \\
\hline & Total & 172 & $100 \%$ \\
\hline \multirow[t]{4}{*}{ 2. How often did you visit the Town? } & Once a week & 103 & $59.88 \%$ \\
\hline & Twice a week & 59 & $34.30 \%$ \\
\hline & Over & 10 & $5.81 \%$ \\
\hline & Total & 172 & $100 \%$ \\
\hline \multirow[t]{7}{*}{ 3. Why you go to the Town? } & Administration & 43 & $25 \%$ \\
\hline & Education & 23 & $13.37 \%$ \\
\hline & Recreation & 13 & $7.56 \%$ \\
\hline & Marketing & 29 & $16.86 \%$ \\
\hline & Religious & 18 & $10.47 \%$ \\
\hline & Job seeking & 46 & $26.74 \%$ \\
\hline & Total & 172 & $100 \%$ \\
\hline
\end{tabular}

Source: Survey Data 2020

In addition table 4.7 also shows how often households visited the Town and why they go to the Town since the Town provides numerous services and functions to the rural people. These services and functions include market, Job, education, administration and the like as presented in table 4.7. The major reason for visiting the Town is market followed by the need for a job (26.74\%). In answering to the question about the main reason for visiting Ambo Town, the majority (16.86\%) sample rural households mentioned that they visited the Town mainly for marketing purpose. About $13.37 \%$ of the sample rural households also visited the Town for educational purpose. Therefore, the Town played a role on the livelihoods of the rural population in terms of employment, marketing, health and education. With regard to employment, it is at the center of all rural-urban migration theories because the search for job is the primary, if not the only, motivation for movement. Then this result indicates that there is high demand of rural population to visit the Town and so this needs more attention to strengthening URLs.

\subsubsection{Rural-Urban Environmental Linkage}

Environmental linkage is manifested when there is flow of natural resource between the two spatial units. It is normal to see environmental linkages between urban and rural area with their positive and negative dimensions. Flow of natural resource from the surrounding rural area to the nearby urban center and the deposition of waste in rural area from the urban area are the major forms of rural-urban environmental linkages. Under this section marketing of forest and forest product, the use of fuel wood and charcoal as sources of energy for cooking by urban households and dumping of domestic and industrial wastes were treated cognizant of the fact that environmental linkages shaped the livelihoods of households in the study area. 
Table 4.8. Rural -Urban Environmental (Resource) Linkage

\begin{tabular}{|c|c|c|c|}
\hline Items & Category & Frequency & Percentage \\
\hline \multirow{3}{*}{$\begin{array}{l}\text { 1. Do you use any waste deployed by the Town } \\
\text { municipality? }\end{array}$} & Yes & 149 & $86.63 \%$ \\
\hline & No & 23 & $13.37 \%$ \\
\hline & Total & 172 & $100 \%$ \\
\hline \multirow[t]{4}{*}{ 2. Which products did you sold to the Town? } & Firewood & 57 & $33.14 \%$ \\
\hline & Charcoal & 76 & $44.19 \%$ \\
\hline & $\begin{array}{c}\text { Construction } \\
\text { materials }\end{array}$ & 39 & $22.67 \%$ \\
\hline & Total & 172 & $100 \%$ \\
\hline \multirow{3}{*}{$\begin{array}{l}\text { 3. Did you sale any resource such as stone to the } \\
\text { Town? }\end{array}$} & Yes & 58 & $33.72 \%$ \\
\hline & No & 114 & $66.28 \%$ \\
\hline & Total & 172 & $100 \%$ \\
\hline
\end{tabular}

Source: Survey Data 2020

Table 4.8 depicts that the dominant types of forest and forest products are wood for construction, firewood and charcoal. All the sample rural households sold the forest and forest products directly to urban consumers. Urban households in the study area used charcoal and wood as the main source of energy for cooking. Urban households used charcoal and/or fire wood for cooking purpose. Urban household's purchased these products directly from rural retailers. The use of construction materials such as stone from rural area by the urban households is also an Environmental rural-urban linkage. As illustrated in table 4.8, about 33.14\% of the sample rural households reported that they sold firewood, charcoal (44.19\%), construction materials $(22.67 \%)$ and stone (for construction) 33.72\% sold to Ambo Town. The solid, liquid and air-borne wastes generated within the Town and transferred to the surrounding rural area have negative environmental impacts, especially on water bodies. These negative impacts was be high when liquid wastes are disposed of without adequate treatment and when solid wastes are dumped on land sites without any measures to limit their effects. The negative impact of environmental linkage of Ambo Town on the surrounding rural area is most not the issues of this study but in this case the study tried to see URLs and the result shows that still as there is the lack of good connection between URLs.

\subsection{The Challenges of Rural-Urban Marketing Linkage}

Table 4.9. Challenges of URLs

\begin{tabular}{|c|c|c|c|}
\hline Items & Category & Frequency & Percentage \\
\hline \multirow{3}{*}{$\begin{array}{l}\text { 1. Poorly integrated rural-urban value chains are missed } \\
\text { opportunities for market integration of rural young producers } \\
\text { and entrepreneurs. }\end{array}$} & Yes & 143 & $83.13 \%$ \\
\hline & No & 29 & $16.86 \%$ \\
\hline & Total & 172 & $100 \%$ \\
\hline \multirow{3}{*}{ 2. Rural youth often lack access to land and finance. } & Yes & 122 & $70.93 \%$ \\
\hline & No & 50 & $29.07 \%$ \\
\hline & Total & 172 & $100 \%$ \\
\hline \multirow{3}{*}{$\begin{array}{l}\text { 3. Inadequate infrastructure and services connecting rural to urban } \\
\text { area limit access to markets. }\end{array}$} & Yes & 143 & $83.14 \%$ \\
\hline & No & 29 & $16.86 \%$ \\
\hline & Total & 172 & $100 \%$ \\
\hline \multirow{3}{*}{$\begin{array}{l}\text { 4. Rural have less access than urban to quality education and } \\
\text { training relevant to the labor market. }\end{array}$} & Yes & 112 & $65.12 \%$ \\
\hline & No & 60 & $34.88 \%$ \\
\hline & Total & 172 & $100 \%$ \\
\hline \multirow{3}{*}{$\begin{array}{l}\text { 5. Many rural youth migrate to cities due to lack of productive and } \\
\text { decent work opportunities in rural area. }\end{array}$} & Yes & 113 & $77.33 \%$ \\
\hline & No & 59 & 22.67 \\
\hline & Total & 172 & $100 \%$ \\
\hline \multirow{3}{*}{$\begin{array}{l}\text { 6. Young migrants and their rural families often rely on informal, } \\
\text { costly and insecure channels to transfer remittances from urban } \\
\text { area. }\end{array}$} & Yes & 109 & $63.37 \%$ \\
\hline & No & 63 & $36.63 \%$ \\
\hline & Total & 172 & $100 \%$ \\
\hline \multirow{3}{*}{ 7. Local traditions and social norms often prevent rural youth. } & Yes & 132 & $76.74 \%$ \\
\hline & No & 40 & $23.26 \%$ \\
\hline & Total & 172 & $100 \%$ \\
\hline
\end{tabular}

Source: Survey Data 2020

On the Table 4.9. Challenges of URLs were presented. To see the challenges, seven items were used. On all items the study was found as an important challenge and problem for integrate URLs net working systems. On the first item "Poorly integrated rural-urban value chains are missed opportunities for market integration of rural young producers and entrepreneurs" about $83.13 \%$ respondents agreed as the presence of challenges on the 
connections of URLs. Moreover, rural youth often lacks access to land and finance as the study found as one of the problems and challenges of URLs which account about $70.93 \%$ respondents supports the presence of the problems. Then this implies the government's poor commitment and performance for many challenges which missed available opportunities for overall integrated system of URLs. The finding also shows that inadequate infrastructure and services connecting rurally to urban area limit access to markets which results the mismatching URLs. As presents in the above table about $83.14 \%$ respondents support the concepts. In addition Rural have less access than urban to quality education and training relevant to the labor market which results poor mobilization and utilization of available resources such as modern between Urban -Rural linkages in the selected Area. As indicated in the above table about 65.12\% support the ideas in the study area. In addition the rest items the respondents reported as the presence of more challenges in the selected Area on URLs. Presence of these problems implies as the government had poor prospects URLs in the selected area. The findings also indicate that young migrants and their rural families often rely on informal, costly and insecure channels to transfer remittances from urban area which accounts about $63.37 \%$ based on their response they had no any change of improvements their URLs. There were challenges on local traditions, and social norms often prevent rural youth which was account about $76.74 \%$ from total respondents. Some socio-cultural values of non-working days were poor systems to break subsistence livelihood and developing coping mechanisms for challenges and problems.

\subsection{Existing Opportunities of UR Marketing}

Table 4.10 Opportunity of URLs

\begin{tabular}{|c|c|c|c|}
\hline Question & Category & Frequency & Percentage \\
\hline \multirow{3}{*}{$\begin{array}{l}\text { 1. Strong rural-urban connectivity allows young people to } \\
\text { diversify their activities and develop businesses along agri- } \\
\text { food value chains. }\end{array}$} & Yes & 155 & $90.12 \%$ \\
\hline & No & 17 & $9.88 \%$ \\
\hline & Total & 172 & $100 \%$ \\
\hline \multirow{3}{*}{$\begin{array}{l}\text { 2. Better access to land, services and urban markets increases } \\
\text { the profitability and sustainability of rural youth's farms and } \\
\text { enterprises. }\end{array}$} & Yes & 147 & $85.47 \%$ \\
\hline & No & 25 & $14.53 \%$ \\
\hline & Total & 172 & $100 \%$ \\
\hline \multirow{3}{*}{$\begin{array}{l}\text { 3. Increased access to good quality and relevant education and } \\
\text { training enables rural youth to find better jobs along agri- } \\
\text { food value chains. }\end{array}$} & Yes & 152 & $88.37 \%$ \\
\hline & No & 20 & $11.63 \%$ \\
\hline & Total & 172 & $100 \%$ \\
\hline \multirow{3}{*}{$\begin{array}{l}\text { 4. Strong URLs create employment opportunities for rural } \\
\text { youth preventing distress migration. }\end{array}$} & Yes & 167 & $97.09 \%$ \\
\hline & No & 5 & $2.91 \%$ \\
\hline & Total & 172 & $100 \%$ \\
\hline \multirow{3}{*}{$\begin{array}{l}\text { 5. Domestic remittances sent through normal channels by } \\
\text { young migrants can lead to productive investments in rural } \\
\text { area. }\end{array}$} & Yes & 165 & $95.93 \%$ \\
\hline & No & 7 & $4.07 \%$ \\
\hline & Total & 172 & $100 \%$ \\
\hline \multirow{3}{*}{$\begin{array}{l}\text { 6. Limiting social exclusion against vulnerable youth can } \\
\text { facilitate their access to productive resources and integration } \\
\text { into inclusive value chains. }\end{array}$} & Yes & 169 & $98.26 \%$ \\
\hline & No & 3 & $1.44 \%$ \\
\hline & Total & 172 & $100 \%$ \\
\hline
\end{tabular}

Source: Survey Data 2020

Table 4.10 presented opportunity of URLs in the selected area. The first item was strong rural-urban connectivity allows young people to diversify their activities and develop businesses along agri-food value chains. On this item about $90.12 \%$ respondents support the ideas. In addition, on the second item on the better access to land, services and urban markets increases the profitability and sustainability of rural youth's farms and enterprises about $85.47 \%$ of respondents respond good ideas on these concepts. The study also shows that increased access to good quality and relevant education and training enables rural youth to find better jobs along agri-food value chains which account about $88.37 \%$ respondents support the ideas. Finally, on the Domestic remittances sent through normal channels by young migrants can lead to productive investments in rural area $(95.93 \%)$ and Limiting social exclusion against vulnerable youth can facilitate their access to productive resources and integration into inclusive value chains $(98.26 \%)$. Then the findings confirm that no more coordination between URLs which support economic development of the selected area.

\subsection{The Existing Practices of Urban Traders Linkages}

Table 4.11 presents the analysis of urban traders as the presence of good linkage of urban to rural and seen the problems which affect traders in the Ambo Town. The types of trade undertake were wholesaler and retailer. Retail traders in the Town were about $66 \%$, and they engaged in retail trade activity. They purchased items from whole sellers in the Towns and surrounding farmers. There was therefore a linkage between retail traders and rural suppliers. Those engaged in the wholesale trade got their items predominantly from Ambo surrounding 
Area focused in this study. The customers for the retailers and whole sellers were both the urban and rural dwellers of Ambo Town surrounds. For grain traders, their main market day is Saturday. About $34 \%$ of the traders were wholesale traders. Majority of these trade activities owned privately which account about $74 \%$ of the sample.

Table 4.11 Results of Urban Traders Linkages

\begin{tabular}{|c|c|c|c|}
\hline Items & Category & Frequency & Percentage \\
\hline \multirow[t]{3}{*}{ 1. What type of trade do you undertake? } & Wholesaler & 17 & $34 \%$ \\
\hline & Retailer & 33 & $66 \%$ \\
\hline & Total & 50 & $100 \%$ \\
\hline \multirow[t]{3}{*}{ 2. Type of business ownership } & Sole & 37 & $74 \%$ \\
\hline & Partnership & 13 & $26 \%$ \\
\hline & Total & 50 & $100 \%$ \\
\hline \multirow[t]{4}{*}{ 4. Source of capital } & Bank & 7 & $14 \%$ \\
\hline & Microfinance & 29 & $58 \%$ \\
\hline & Self & 14 & $28 \%$ \\
\hline & Total & 50 & $100 \%$ \\
\hline \multirow{3}{*}{$\begin{array}{l}\text { 5. From where do you purchase the } \\
\text { products you sale? }\end{array}$} & Rural area & 43 & $86 \%$ \\
\hline & Out of the region & 7 & $14 \%$ \\
\hline & Total & 50 & $100 \%$ \\
\hline \multirow{5}{*}{$\begin{array}{l}\text { 6. What are the main marketing problems } \\
\text { associated with the Town? }\end{array}$} & Warehouses & 17 & $34 \%$ \\
\hline & Transportation & 13 & $26 \%$ \\
\hline & Market network & 11 & $22 \%$ \\
\hline & Financial institutions & 9 & $18 \%$ \\
\hline & Total & 50 & $100 \%$ \\
\hline \multirow{3}{*}{$\begin{array}{l}\text { 7. Is there service from the government } \\
\text { body on networking URLs? }\end{array}$} & Yes & 22 & $44 \%$ \\
\hline & No & 28 & $56 \%$ \\
\hline & Total & 50 & $100 \%$ \\
\hline
\end{tabular}

Source: Survey Data 2020

The main sources of capital were bank, microfinance and self. The main sources according to this study were microfinance which accounts about $58 \%$ of total sample. The place of item purchase was rural area which accounts $86 \%$ of the sample. The onion, tomato and potato wholesale traders sell their item to retailers on Friday evening and Saturday morning. While the retailers sell their items on Saturday. In, general, Saturday is the main market day for this type of trade. The traders got vegetables from the rural farmers and again sell the spices to these rural dwellers. Even if there are different activities to link urban rural there are plentiful of problems which hinder participants. The challenges were market network, transportation, warehouse and financial institution.

\section{Conclusion and Recommendations}

\subsection{Conclusion}

Based on the above summary of the above repots the following conclusions were drawn:

$>$ Agricultural Marketing linkage is manifested when the urban dwellers and traders purchase the agricultural produce from the rural households.

$>$ However, marketing linkage between the agricultural producers and urban consumers is mostly provided through a network of traders or intermediaries were not such promising. This point out the poor of marketing connection between UR in case of less understanding marketing activities.

$>$ Rural -urban consumption linkage in case of urban goods and merchandise, which are imported or domestically manufactured, flow from urban to rural area.

$>$ There were good demand in the side of the farmers as analyzed in the previous chapter but it lacks to create good relationship with rural farmers.

$>$ Services linkage Towns provide numerous services and functions to the hinterland people.

$>$ Such weak service had its own impact on weakening the rural-urban linkage through the low supply of agricultural productivity.

$>$ These services and functions include market, job, education, and administration.

$>$ As the result discusses there was no more good connection which implies poor visiting system in the selected area or Area.

$>$ At it is obvious environmental linkages can also have a negative element. The solid, liquid and air-borne wastes generated within the Town and transferred to the surrounding rural area have negative environmental impacts, especially on water bodies. 


\subsection{Recommendations}

Based on the results made so far, the following recommendations are made in order to promote the existing URLs and thereby to stimulate the sustainable URLs.

$>$ It is essential to improve agricultural productivity and enhance family planning as a means to reduce poverty and improve their livelihood.

$>$ Training, consultancy and information provision can facilitate the implementation of these mechanisms.

$>$ The function of FTCs is so crucial in this regard.

$>$ It is also important to create awareness on family planning in order to reduce the pressure on agricultural land in the study area.

$>$ Expand the existing industries which are found in the Town, to create more job opportunity for the rural people.

The rural households can have sufficient agricultural land; as a result their productivity will boost.

$>$ Develop marketing skills, and access to credit, need be taken to expand these activities and minimize technical and liquidity constraints that limit households to join these activities.

$>$ It is possible to enhance the livelihood of many people by providing an access to transport services.

$>$ Making the transport service an accessible and affordable would strengthening the rural-urban linkage.

\section{Reference}

$>$ Adebayo, A. (2005). "Enhancing Positive Urban-Rural Linkage Approach to Sustainable Development \& Employment Generation in South Africa". In UN Human Settlement Program, 2005. Urban-Rural Linkage Approach to Sustainable Development. PP 43-61.

$>$ Braun, J. (2007). URLsfor Growth, Employment, \& Po Reduction: Ethiopian Economic Association Fifth International Conference on the Ethiopian Economy June7-9, 2007 Addis Ababa.

$>$ Chowdhury, S., Asfaw, N., \& Torero, M. (2005). Market Institutions: Enhancing the Value of Rural- Urban Links. FCND Discussion Paper 195 Washington, DC.

> Douglass, M. (1998). A Regional Network Strategy for Reciprocal Rural-Urban Linkage. TWPR, Vol.2, No.1.

$>$ Mesfin, W. (1995). The Role of Small Market Towns in Integrating the Rural-Urban Economy: Case of Ten Market Towns in Sub-District of Cheliya in Gibatand Mecha Awraja, Unpublished MA Thesis, AAU.

$>$ Mohammed, S. (2007). Livelihood Strategies \& their Implications for Rural-Urban Linkages: The case of Wolenkomi Town \& the Surrounding Rural Area Working Papers on Population \& Land Use Change in Central Ethiopia, nr. $10 \mathrm{http} / / /$ www.svt.ntnu.no/geo/Doklager/Acta/serie_a_18_mohammed.pdf. Accessed on December 08, 2008.

> Okpala, D. (2003). Promoting the Positive URLs Approach to Sustainable Development \& Employment creation: The Role of UN HABITAT Second FIG Regional Conference Karraked, Morocco.

$>$ Tacoli, C. (1998b). Bridging the Divide: Rural-Urban Interactions \& Livelihood Strategies. IIED, Gatekeeper Series No. 77.

$>$ Tacoli, C. (2008). Links between Rural \& Urban Development in Africa \& Asia. United Nations Secretariat. IIED, New York.

$>$ Tassew, W. (2002). Promoting Farm/Non-farm Linkage for Rural Development: The case of Rural Farm/non-Farm Income Linkage in Northern Ethiopia, Economic \& Social Department, Rome, Italy.

$>$ Tegegne, G. (2001).URLs under different Systems: The Case of Coffee \& Non Coffee Growing Regions in Ethiopia. OSSREA, Ethiopia.

$>$ Tesfaye, D. (1993). A Study of Rural-Urban Integration towards Determining a Regional Center under the Urbanization Level \& Development Potentials of Sidamo: Seminar Proceedings Regional Development Problems in Ethiopia, Ambo II.

$>$ UNDP. (2000). Rural-Urban Linkage: An Emerging Policy Priority. Bureau for Development, New York.

$>$ Yigremew, A. (2000). Issues in Rural Development: Proceedings of the Inaugural Workshop of the Forum for Social Studies 18 Sep.1998, Addis Ababa. 